\title{
3 次元非構造格子流体シミュレーターヘの GLS 乱流クロージャーモデルの組み込みと検証 \\ PERFORMANCE OF GLS TURBULENCE CLOSURE MODEL IMPLEMENTED IN 3D UNSTRUCTURED HYDRODYNAMIC SIMULATOR
}

\author{
新谷哲也 \\ Tetsuya SHINTANI
}

正会員 博士 (工) 首都大学東京助教＼cjkstart都市基盤環境コース（１１92-0397 東京都八王子市南大沢 1-1）

\begin{abstract}
The generic length scale (GLS) turbulence closure model has been implemented to an object-oriented 3D hydrodynamic simulator, Fantom Unstructured, to investigate geophysical flows. This paper summarizes the basics of the GLS turbulence closure model, its parameters and the discretization on an orthogonal unstructured grid. The performance of the present simulator with the GLS turbulence closure model was examined for open channel steady flow and mixed-layer deepening problems, then the computed results were compared with analytical and empirical solutions. The choice of the two-equation model and stability function affects the vertical distribution of turbulence quantities, however, the reasonable agreements are obtained for the vertical distribution of the horizontal velocity and mixed-layer depth between computed results and the solutions.
\end{abstract}

Key Words: $\quad$ Turbulence closure, hydrodynamic simulator, open channel, mixed-layer deepening

\section{1.はじめに}

湖沼や海洋をはじめ, 多くの水域において広範囲か つ長期間の流動解析が盛んに行われている.現地スケー ルの流れは基本的に乱流であり，また兴の多くが成層 化している . 弚のため, 正確に流動・混合現象を予測す るためには , 乱流エネルギーが熱エネルギーへと散逸 していく過程だけではなく, ポテンシャルエネルギー へと変換される効果も含めて再現する必要がある. 光 れ故，これまでに成層化関数による渦動粘性・渦拡散 係数の表現 ${ }^{1)}$, 連行現象をモデル化した混合スキーム 2)，Monin-Obukov の相似則に基づいた KPP モデル ${ }^{3)}$, 乥して 1980 年代頃からレイノルズ平均に基づいて乱流 エネルギーと乱れの長さスケールの輸送方程式を解く 2 方程式モデル ${ }^{4,5,6)}$ 八発展的に混合層モデルが提案さ れ広く使われてきた．近年，計算機能力の向上によっ て LES や DNS の適用範囲が拡大しているが, 未だ広 範囲・長期間における実スケールの流動解析は困難であ り，当面は 2 方程式モデルが主流になると予想される

代表的な 2 方程式モデルとしては,$k-\omega$ モデル ${ }^{4)}, k-$ $\epsilon^{5)}$ モデル, 光して海洋では長らく Mellor-Yamada Level 2.5 モデル $^{6}$ が広く利用されてきている．また，近年， Umlauf and Burchard ${ }^{7)}$ は，2 方程式モデルを Generic Length Scale 乱流クロージャーモデル (以下 , GLS モデ ル)として統一する試みを行っている .このモデルでは， モデル内のパラメータを変更させることで乱れの長さ スケールに関する方程式を変化させ, 樣々な 2 方程式モ
デルへと帰着させることが出来る . 彼らはこのモデル を鉛直一次元流動・混合モデルである $\mathrm{GOTM}^{8)}$ に代数 2 次モーメントクロージャーモデルと共に組み込んで良 好な結果を得ている。.また, 近年, 各研究機関は独自の 3 次元流動モデルに GLS モデルを組み込みを行う試み か増えてきている. 例えば , Zang et al. ${ }^{9)}$ は ELCIRCに , Warner et al. ${ }^{10)}$ は ROMS に , Wang et al. ${ }^{11)}$ は SUNTANS に, 光して, Hill et al. ${ }^{12)}$ は Fluidity-ICOM に GLS モデ ルを組み込み，光の再現性を検証している。

このように現在まで, 多くの組み込みと検証が続い ている理由として, 乱流エネルギーや乱れの長さスケー ルに関する方程式は数值的に不安定であり, 境界条件 や離散化に注意が必要なこと ${ }^{13)}$, 成層場の影響をはじ め代数 2 次モーメントクロージャーの情報を反映する Stability function の違いが 2 方程式モデルの違いよりも 結果に与える影響が大きい場合があること ${ }^{11)}$, 組み込 み先のシミュレータの離散化方法が異なること等が挙 げられる . 兴のため, より多くの構造の異なるシミュ レーターでGLS モデルを検証して報告することは，今 後のモデル利用者や開発者に有益な情報を与えること になると思われる．しかしながら，海外での積極的な 採用に比較して, 国内においては GLS 乱流モデルに関 する情報は非常に少なく, 著者の知る限り, 森ら ${ }^{14)} に$ よるROMS を用いた研究, 木村 ${ }^{15)}$ による POM へ組み 込みが紹介されているのみである。

乥こで本研究では, 著者らが開発中の3 次元非構造 格子流体シミュレーター ${ }^{16)} へ$ へ GLS モデルの組み込 
みを通じて得られた知見をできる限り詳細に報告する。 光して, シミュレーターの検証として, Warner et al. ${ }^{10)}$ によって行われた開水路定常乱流と風応力に伴う混合 層低下現象を選び, シミュレーターの計算精度, 光し て乱流モデルと Stability function の選択によって生じる 差異を検討する .

\section{GLS モデル}

(1) 乱流量の輸送方程式

GLS モデルは , 運動方程式と連続式の他に , 以下に 示す乱流エネルギー $k$ と一般化された乱れの長さスケー ルに関する量 $\psi$ の輸送方程式を連立して解く.

$$
\begin{gathered}
\frac{D k}{D t}=\frac{\partial}{\partial z}\left(\frac{v_{M}}{\sigma_{k}} \frac{\partial k}{\partial z}\right)+P+B-\epsilon \\
\frac{D \psi}{D t}=\frac{\partial}{\partial z}\left(\frac{v_{M}}{\sigma_{\psi}} \frac{\partial \psi}{\partial z}\right)+\frac{\psi}{k}\left(c_{1} P+c_{3} B-c_{2} \epsilon\right)
\end{gathered}
$$

ここで, $D$ は実質微分， $z$ は鉛直上向きの座標， $v_{M}$ は 鉛直渦動粘性係数， $\sigma_{k}$ と $\sigma_{\psi}$ は光れ光れ $k$ と $\psi$ の乱流 シュミット数, $\epsilon$ は乱流エネルギーの散逸率, 光して $P$

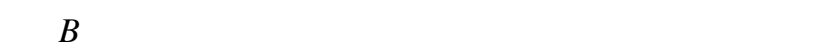
以下で表される.

$$
\begin{gathered}
P=v_{M} M^{2}, M^{2}=\left(\frac{\partial U}{\partial z}\right)^{2} \\
B=-v_{H} N^{2}, N^{2}=-\frac{g}{\rho_{0}} \frac{\partial \rho}{\partial z}
\end{gathered}
$$

ここで, $U$ は水平方向流速， $v_{H}$ は鉛直渦拡散係数, $g$ は 重力加速度 . $\rho_{0}$ は参照密度,$\rho$ は密度である .また $, M, N$

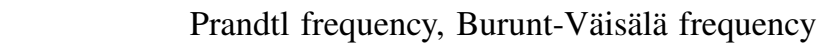
と呼ばれる. 产の他式中に現れる係数に関しては表-1 に示した ${ }^{10)}$.ただし,$c_{3}^{+}$は安定成層時, $c_{3}^{-}$は不安定成 層時に用いる $c_{3}$ の值である. 渦動粘性係数の表記には， Mellor and Yamada $\left.{ }^{6}\right)$ やWarner et al. ${ }^{10)}$ が採用している 表記法と Burchard ${ }^{13)}$ 等の表記法があるが，後に述べる 各種 Stability function の統一的で簡潔な表現との兼ね合 いから, 本研究では Umlauf and Burchard ${ }^{17)}$ のパラメー ター及び表記法を採用して, 以下のように表現するこ ととした .

$$
\begin{aligned}
& v_{M}=c_{\mu} \frac{k^{2}}{\epsilon} \\
& v_{H}=c_{\mu}^{\prime} \frac{k^{2}}{\epsilon}
\end{aligned}
$$

ここで， $c_{\mu}$ 及び $c_{\mu}^{\prime}$ は光れ光れ後に説明する運動量とス カラー量に関する Stability functionである . また , 乱れ の散逸率 $\epsilon$ は以下の式で与えられる .

$$
\epsilon=\left(c_{\mu}^{0}\right)^{3 / 4} \frac{k^{3 / 2}}{\ell}
$$

ここで $c_{\mu}^{0}$ は経験的パラメーター, $\ell$ は乱流の長さスケー ルである.$\ell$ は以下に示す $\psi$ との関係式から求めるこ
表-1 $k-\epsilon, k-\omega$, gen モデルにおける係数

\begin{tabular}{|c|c|c|c|}
\hline & $\begin{array}{c}k-\epsilon \\
\psi=\left(c_{\mu}^{0}\right)^{3 / 4} k^{2 / 3} \ell^{-1}\end{array}$ & $\begin{array}{c}k-\omega \\
\psi=\left(c_{\mu}^{0}\right)^{-1 / 4}{ }_{k^{1 / 2} \ell^{-1}}\end{array}$ & $\begin{array}{c}\text { gen } \\
\psi=\left(c_{\mu}^{0}\right)^{1 / 2} k^{1} \ell^{-2 / 3}\end{array}$ \\
\hline$p$ & 3.0 & -1.0 & 2.0 \\
\hline$m$ & 1.5 & 0.5 & -0.67 \\
\hline$n$ & -1.0 & -1.0 & 10.0 \\
\hline$\sigma_{k}$ & 1.0 & 2.0 & 0.8 \\
\hline$\sigma_{\psi}$ & 1.3 & 2.0 & 1.07 \\
\hline$c_{1}$ & 1.44 & 0.555 & 1.0 \\
\hline$c_{2}$ & 1.92 & 0.833 & 1.22 \\
\hline$c_{3}^{+}$ & 1.0 & 1.0 & 1.0 \\
\hline$c_{3}^{-}(C A)$ & -0.63 & -0.64 & 0.05 \\
\hline$c_{3}^{-}(K C)$ & -0.52 & -0.58 & 0.10 \\
\hline
\end{tabular}

表-2 Stability functionにおける経験的パラメーターの值

\begin{tabular}{|c|c|c|c|c|c|c|}
\hline & $c_{1}$ & $c_{2}$ & $c_{3}$ & $c_{4}$ & $c_{5}$ & $c_{6}$ \\
\hline $\mathrm{CA}$ & 5.000 & 0.800 & 1.968 & 1.136 & 0.000 & 0.4000 \\
\hline $\mathrm{KC}$ & 6.000 & 0.320 & 0.000 & 0.000 & 0.000 & 0.4000 \\
\hline \hline & $c_{b 1}$ & $c_{b 2}$ & $c_{b 3}$ & $c_{b 4}$ & $c_{b 5}$ & $c_{b 6}$ \\
\hline $\mathrm{CA}$ & 5.950 & 0.600 & 1.000 & 0.000 & 0.333 & 0.7200 \\
\hline $\mathrm{KC}$ & 3.728 & 0.700 & 0.700 & 0.000 & 0.200 & 0.6102 \\
\hline
\end{tabular}

とが出来る．

$$
\psi=\left(c_{\mu}^{0}\right)^{p / 4} k^{m} \ell^{n}
$$

ここで $p, m, n$ は表-1 に示すように 2 方程式モデルを規 定するためのパラメーターである. 本研究では， 2 方 程式モデルのうち壁関数を必要としない $k-\epsilon, k-\omega$, Umlauf and Burchard によって新たに定義された 2 方程 式モデル (本論文中では gen と呼称する) ${ }^{7,10)}$ の 3 種 類のモデルに限定して検討を行うこととする .

\section{(2) Stability function}

本研究では, 境界層近似の下に導かれた代表的なStability function である, Kanta and Clayson (以下 KC) ${ }^{18)}$ と Canuto et al. (以下 $\mathrm{CA})^{19)}$ の 2 種類を検証する. 運動 量とスカラー量の Stability function, $c_{\mu}$ と $c_{\mu}^{\prime}$ に関する 代数的表現は光れ光れ以下の式で与えられる .

$$
\begin{aligned}
& c_{\mu}=\frac{n_{0}+n_{1} \alpha_{N}+n_{2} \alpha_{M}}{d_{0}+d_{1} \alpha_{N}+d_{2} \alpha_{M}+d_{3} \alpha_{N} \alpha_{M}+d_{4} \alpha_{N}^{2}+d_{5} \alpha_{M}^{2}} \\
& c_{\mu}^{\prime}=\frac{n_{b 0}+n_{b 1} \alpha_{N}+n_{b 2} \alpha_{M}}{d_{0}+d_{1} \alpha_{N}+d_{2} \alpha_{M}+d_{3} \alpha_{N} \alpha_{M}+d_{4} \alpha_{N}^{2}+d_{5} \alpha_{M}^{2}}
\end{aligned}
$$

ここで， $\alpha_{M}$ と $\alpha_{N}$ は光れ光れ以下の式で表される.

$$
\begin{aligned}
\alpha_{M} & =\frac{k^{2}}{\epsilon^{2}} M^{2} \\
\alpha_{N} & =\frac{k^{2}}{\epsilon^{2}} N^{2}
\end{aligned}
$$


また，弚の他の係数は以下で与えられる．

$$
\begin{aligned}
d_{0}= & 36 \mathcal{N}^{3} \mathcal{N}_{b}^{2} \\
d_{1}= & 84 a_{5} a_{b 3} \mathcal{N}^{2} \mathcal{N}_{b}+36 a_{b 5} \mathcal{N}^{3} \mathcal{N}_{b} \\
d_{2}= & 9\left(a_{b 2}^{2}-a_{b 1}^{2}\right) \mathcal{N}^{3}-12\left(a_{2}^{2}-3 a_{3}^{2}\right) \mathcal{N N}_{b}^{2} \\
d_{3}= & 12 a_{5} a_{b 3}\left(a_{2} a_{b 1}-3 a_{3} a_{b 2}\right) \mathcal{N} \\
& +12 a_{5} a_{b 3}\left(a_{3}^{2}-a_{2}^{2}\right) \mathcal{N}_{b}+12 a_{b 5}\left(3 a_{3}^{2}-a_{2}^{2}\right) \mathcal{N N}_{b} \\
d_{4}= & 48 a_{5}^{2} a_{b 3}^{2} \mathcal{N}+36 a_{5} a_{b 3} a_{b 5} \mathcal{N}^{2} \\
d_{5}= & 3\left(a_{2}^{2}-3 a_{3}^{2}\right)\left(a_{b 1}^{2}-a_{b 2}^{2}\right) \mathcal{N} \\
n_{0}= & 36 a_{1} \mathcal{N}^{2} \mathcal{N}_{b}^{2} \\
n_{1}= & -12 a_{5} a_{b 3}\left(a_{b 1}+a_{b 2}\right) \mathcal{N}^{2}+ \\
& +8 a_{5} a_{b 3}\left(6 a_{1}-a_{2}-3 a_{3}\right) \mathcal{N N}_{b}+36 a_{1} a_{b 5} \mathcal{N}^{2} \mathcal{N}_{b} \\
n_{2}= & 9 a_{1}\left(a_{b 2}^{2}-a_{b 1}^{2}\right) \mathcal{N}^{2} \\
n_{b 0}= & 6 a_{b 3}^{2} \mathcal{N}^{3} \mathcal{N} b \\
n_{b 1}= & 12 a_{5} a_{b 3}^{2} \mathcal{N}^{2} \\
n_{b 2}= & 9 a_{1} a_{b 3}\left(a_{b 1}-a_{b 2}\right) \mathcal{N}^{2} \\
& +\left(6 a_{1}\left(a_{2}-3 a_{3}\right)-4\left(a_{2}^{2}-3 a_{3}^{2}\right)\right) a_{b 3} \mathcal{N N}_{b}
\end{aligned}
$$

ここで, $\mathcal{N}$ と $\mathcal{N}_{b}$ は乱流の生成と散逸が釣り合った（局 所平衡) 状態を仮定して以下で与えられる ${ }^{17)}$.

$$
\mathcal{N}=\frac{c_{1}}{2}, \mathcal{N}_{b}=c_{b 1}
$$

また上で示した係数群に含まれる係数は，

$$
\begin{aligned}
& a_{1}=\frac{2}{3}-\frac{1}{2} c_{2}, a_{2}=1-\frac{1}{2} c_{3}, a_{3}=1-\frac{1}{2} c_{4} \\
& a_{4}=\frac{1}{2} c_{5}, a_{5}=\frac{1}{2}-\frac{1}{2} c_{6} \\
& a_{b 1}=1-c_{b 2}, a_{b 2}=1-c_{b 3}, a_{b 3}=2\left(1-c_{b 4}\right) \\
& a_{b 4}=2\left(1-c_{b 5}\right), a_{b 5}=2 c_{b b}\left(1-c_{b 5}\right)
\end{aligned}
$$

となり，さらにこれらの式に含まれる経験的に決めら れるパラメーターは Stability functionによって異なり， 表-2 に示すような值となる．また， $c_{\mu}^{0}$ は密度成層が存 在しない対数分布領域を仮定し, 上で与えられたパラ メーターから次のように求めることが出来る ${ }^{17)}$.

$$
c_{\mu}^{0}=\frac{a_{2}^{2}-3 a_{3}^{2}+3 a_{1} \mathcal{N}}{3 \mathcal{N}^{2}}
$$

\section{3. 非構造格子流体シミュレーター}

\section{(1) シミュレーターの概要}

本研究では, 新谷·中山 ${ }^{16)}$ によって開発された 3 次元 非構造格子流体シミュレーターFantom Unstructured に GLS モデルを組み込んだ . シミュレーターの設計概念や 基本的な検証については参考文献を参照して頂きたいが， このシミュレーターは, 生物細胞の組織構造を模したオ ブジェクト群によって構成されている . 基本構造は図1(a)に示すような諸量の蓄積を主に担うCell (細胞) 才 ブジェクトと主にCell 間の相互作用 (フラックス)を担う 鉛直·水平の Membrane (細胞膜) オブジェクトで構成さ

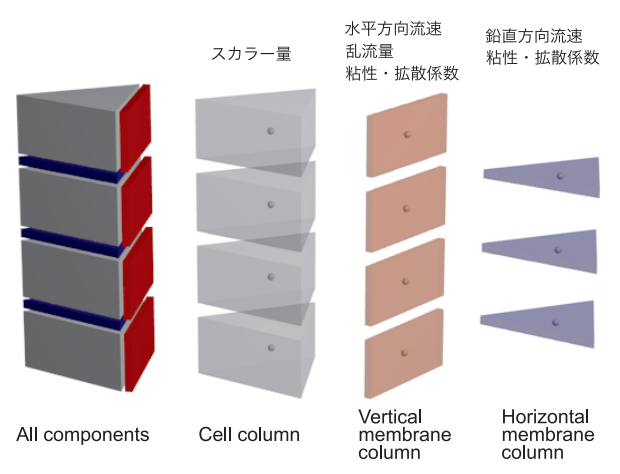

(a) Cell · Membrane構造及び変数配置

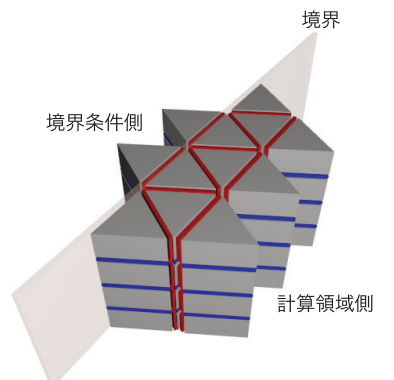

(b) 開境界条件

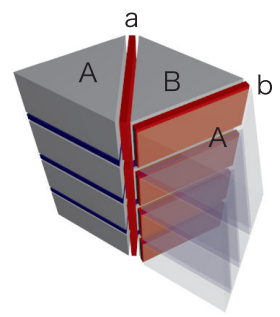

(c) 周期境界条件
図-1 Cell ・ Membrane 構造の概要と側方境界条件

れている.さらに, 同種のオブジェクトが鉛直的につな がつた column 構造オブジェクト (Cell column, Horizontal membrane column, Vertical membrane column) となりグ ループとして機能する（例えば陰的な鉛直拡散計算）。 光れ光れのオブジェクトは単純な命令伝達を受け, 光れ 光れが知る複雑な処理を行う仕組みとなっている。従属 変数に関しては, 任意のスカラー量は Cell に蓄えられ， Vertical membrane 及び Horizontal membrane には流速と 鉛直渦動粘性·拡散係数, さらに Vertical membraneには 乱流量 $(k$ と $\psi)$ が定義されている. 既往の研究 ${ }^{9110) 11) 12) ~}$ において, 乱流量の定義位置は樣々である. 本研究で用 いた非構造格子シミュレーターでは, 試行錯誤の結果， 鉛直の速度勾配が直接求められる Vertical Membrane に 定義することで安定した結果を得ることができた 。

GLS モデルの他に, 前報 ${ }^{16)}$ から行われたシミュレー ターへの変更点としては, 水面や非静水圧の陰的な計算 て現れる連立方程式の解法にC++の高速行列演算ライブ ラリーEigen ${ }^{20)}$ (不完全 LU 分解前処理付き BiCGSTAB) を利用していること，光して下に示す側方境界条件を 導入したことが挙げられる．

\section{（2）水面·底面の境界条件}

中規模以上の現地スケールの流動現象を解析する際 には, 底面直上の計算点が粘性底層の内部に入ること はほとんど無いため, 底面直上の Vertical membrane(の 中心点) か対数領域内に存在すると仮定して良い，光こ で，底面はスリップ条件とし，弚の代わりに底面抗力 を導入する . 底面抗力 $\tau_{b}$ は一般的に以下の式によって 
与えられる .

$$
\tau_{b}=\rho_{0} u_{*}^{2}=-\rho_{0} C_{D}|U| U
$$

ここで, $u_{*}$ は底面摩擦速度である.$C_{D}$ は抗力係数であ り， $C_{D}=0.0026$ 程度の一定値を与えることも多いが， 対数分布則に整合するように決めることも出来る. 対 数分布則から水平流速の鉛直分布は以下のように表現 できる .

$$
\frac{U}{u_{*}}=\kappa \ln \left(z / z_{0}\right)
$$

ここで, $\kappa$ はカルマン定数,$z_{0}$ は粗度高さ (本研究では $z_{0}=0.005 \mathrm{~m}$ とした) である.式(14),(15)より，抗力係 数 $C_{D}$ を導出すると以下の式で表され, 本研究では抗力 係数の評価にこの式を用いた .

$$
C_{D}=\left(\frac{\kappa}{\ln \left(z / z_{0}\right)}\right)^{2}
$$

底面抗力は水平方向運動量に対するシンク項となるた め, 抗力項は数值的安定化のために $U$ に関する鉛直拡 散計算に加えて陰的に計算する.具体的には式(14)で絶 対値の付いていない $U$ を末知 $(\mathrm{n}+1)$ の変数として解を 求める.本シミュレーターは既報 ${ }^{16)}$ の通り，サブグリッ ドスケールの地形表現が可能となるように , Partial step 法による離散化に対応している．しかしながら，Partial step を用いた場合，底面付近における鉛直格子間隔の急 激な変化に起因する速度勾配の近似誤差が大きくなり， 対数分布から逸脱することが最近 Platzek et al. ${ }^{21)}$ に指摘 されている.弚のため, 本研究では, 通常の z-coordinate を利用して計算を行う. 彼らが提案している改善手法 の導入は今後の課題とする . 一方, 水面では, 近藤 ${ }^{22)}$ によるバルク式によってフラックスを求め, 運動量の ソースとして陽的に水面 Cell に導入する.

乱流量 $k$ と $\psi$ に関しては，2 種類の境界条件 (Dirichlet 型と Neumann 型) が提案されている ${ }^{13)}$ が , Neuman 型 の境界条件が数值的に安定，かつ合理的な鉛直渦動粘 性係数の分布が得られるとされている. 本研究におい ても以下に示す Neumann 型の境界条件を水面と水底に 課した。

$$
\begin{gathered}
\frac{v_{M}}{\sigma_{k}} \frac{\partial k}{\partial z}=0 \\
\frac{v_{M}}{\sigma_{\psi}} \frac{\partial \psi}{\partial z}=n \frac{v_{M}}{\sigma_{\psi}}\left(c_{\mu}^{0}\right)^{p / 4} \kappa^{n} k^{m} z^{n-1}
\end{gathered}
$$

この Neuman 条件のまま計算しても結果に大きな違い は生じないが，本計算では次に示す拡散計算後に底面 直上の計算点の $k$ と $\epsilon$ の值を壁法則に基づいた值に置 き換えることで流速分布がより対数分布にフィットする 結果となった .

\section{(3) $k$ と $\psi$ に関する鉛直拡散方程式}

乱流量 $k$ と廿はいずれも Vertical membrane に定義さ れているため, Vertical membrane column (図-1 参照)
について離散化を行う. Wang et al. ${ }^{11)} に も$ 述べられて いるように, 底面抗力の場合と同樣, 散逸項を陽的に 扱うと数值的に不安定になる $(k$ と $\psi$ は常に正值でな ければならない）.また， $k$ と $\psi$ の方程式には， $\epsilon$ に関 係する項の他に, 浮力項 $B$ が成層状態によっては散逸 項になりうる (一方, せん断による生成項 $P$ は常に正). 乥こで, Wang et al. ${ }^{11)}$ らか採用したように， $k$ の方程式 に関して言えば， $P+B$ が正の場合は, $\epsilon$ に関する項の みを陰的にし，負の場合には $B$ と $\epsilon$ の項の両方をまと めて陰的に扱うことで数值的な不安定を避ける. 鉛直 の拡散方程式は一次元の TDMA 法で解くが，光の際， 上述の $k$ と $\psi$ の境界条件は, 行列計算の既知項に組み 込む形 (陽的に扱う) でまとめて計算を行う.最終的 に得られた $\psi$ から $\epsilon$ を求める際には, Galperin et al. ${ }^{23)}$ によって提案されている制限を適用した。

$$
\epsilon \geq \frac{c_{\mu}^{0^{3 / 4} k N^{2}}}{\sqrt{0.56}}
$$

\section{（4）側方境界条件}

はじめに述べた樣に, 本研究ではモデルの検証に, 開 水路定常乱流と風応力に伴う混合層低下の計算を利用 しているが，両者の計算では光れ光れ，流入境界条件 (上流) - 開境界条件 (下流), 光して周期境界条件が必

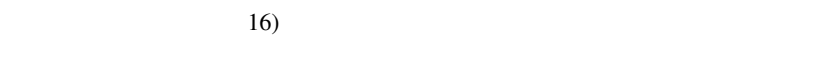
ていないため，ここで補足的な説明を行う．

まず，流入境界については，流入によって生じる体 積フラックスと各変数のフラックスを対象となる Cell へ組み込み, 連続式と輸送方程式に反映させることで 再現する。

開境界条件に関しては図-1(b)に示すように，開境界を 適用する部分に境界条件用 Vertical membrane column を 設置し，光の外側に境界条件用 Cell column を設置する。 実際のシミュレータでは, 開境界用の Vertical membrane column の設置場所を指定すると, 光の Vertical membrane column に線対称な形て計算領域側の Cell column と同樣な形状の境界条件用 Cell column を境界外側に生 成する . 境界条件用 Cell column は変数の時間発展計算 には参加せず，ユーザーが与えた境界条件を受け入れ， 兴の影響か境界条件用 Vertical membrane column を通 じて計算領域へと及ぶ．

周期境界条件に関しては, 図-1(c) に最も単純な 1 次 元の例を示す．まず，2つの Cell column (図中，A, B) と 2つの Vertical membrane column(図中，a, b) を考え る.左側に位置する Vertical membrane column(a) は左右 に隣接している 2 つの Cell column(A, B) をリンクして 相互作用を担当する . 一方, 右側の Vertical membrane column(b) はすぐ左に位置する Cell column(B) と再びも う一つの Cell column(A) をリンクして相互作用を計算 する. 弚の結果, 循環する計算となり周期境界条件が 実現される。 


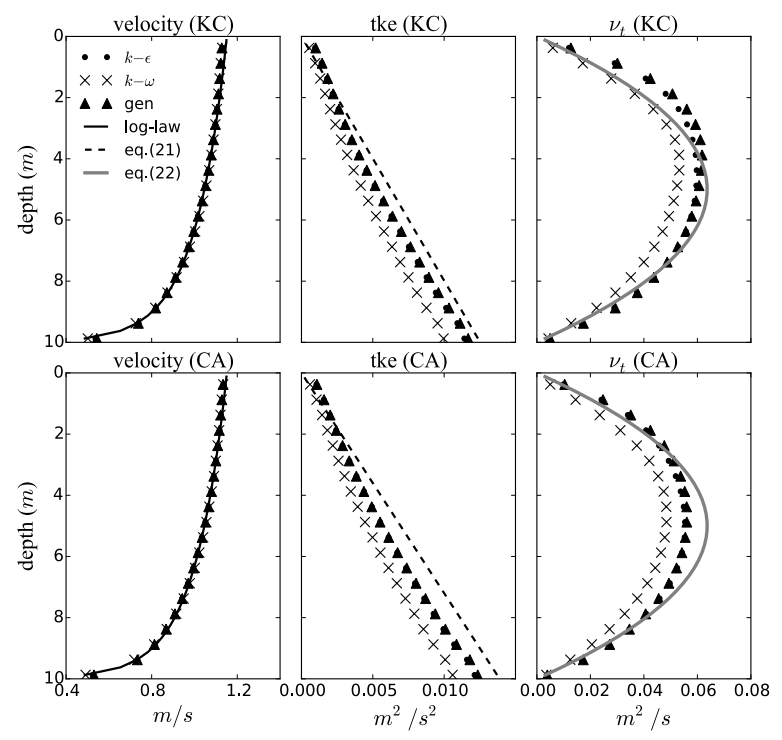

図-2 開水路乱流の比較結果 (上 : $\mathrm{KC}, 下: \mathrm{CA}$ ) 左 : 流速, 中 : 乱流エネルギー, 右 : 渦動粘性係数

\section{4. 精度検証}

\section{(1) 定常開水路流れ}

Warner et al. ${ }^{10)}$ に習って定常開水路流れを計算し，水 平流速の対数分布則, 乱流エネルギーの直線分布, 渦動 粘性係数の放物線分布を基準に結果の検討を行う. 計 算では，一定勾配の斜面 $\left(4.0 \times 10^{-5}\right)$ を水深 $10 \mathrm{~m}$ で流 下する開水路を考える.境界条件としては, 上流側で単 位幅当たり $10.0 \mathrm{~m}^{3} \mathrm{~s}^{-1}$ の流量を与え，下流端は水深 $10 \mathrm{~m}$ の開境界 (Clamped boundary) とした . Cell オブジェク 卜の形状は, 水平方向が一辺 $200 \mathrm{~m}$ の正三角形, 光し て鉛直方向は $0.25 \mathrm{~m}$ とし, 水平・鉛直方向とも同じ形 状のセルを積み重ねた . また, 計算時間ステップは 30 秒とした . 十分に発達した流れを再現するために水路 の長さは $8 \mathrm{~km}$ として下流端から $400 \mathrm{~m}$ 上流における諸 量の鉛直分布を検討した .

壁法則から得られる理論的な摩擦速度 $u_{b}^{*}$, 乱流エネ ルギー分布，光して放物線形状を仮定した渦粘性係数 分布の代数的表現は以下の式で与えられ, 図-2 内で比 較に用いられる10)。

$$
\begin{aligned}
u_{b}^{*} & =\frac{\kappa \bar{u}}{\ln \frac{H}{z_{0}}-1+\frac{z_{0}}{H}} \\
k & =\frac{\left(u_{b}^{*}\right)^{2}}{\sqrt{c_{\mu}^{0}}}\left(1-\frac{z}{H}\right) \\
v_{t} & =\kappa u_{b}^{*} z\left(1-\frac{z}{H}\right)
\end{aligned}
$$

ここで， $\bar{u}$ は断面平均流速， $H$ は全水深である .

図-2 は定常開水路乱流の検証結果を示している．ま ず, 左側に示す水平流速の鉛直分布は, 乱流モデルや Stability function に関係なくWarner et al. ${ }^{10)}$ と同樣に対 数分布則 (式 (15)) と概ね合致している. 一方, 乱流工

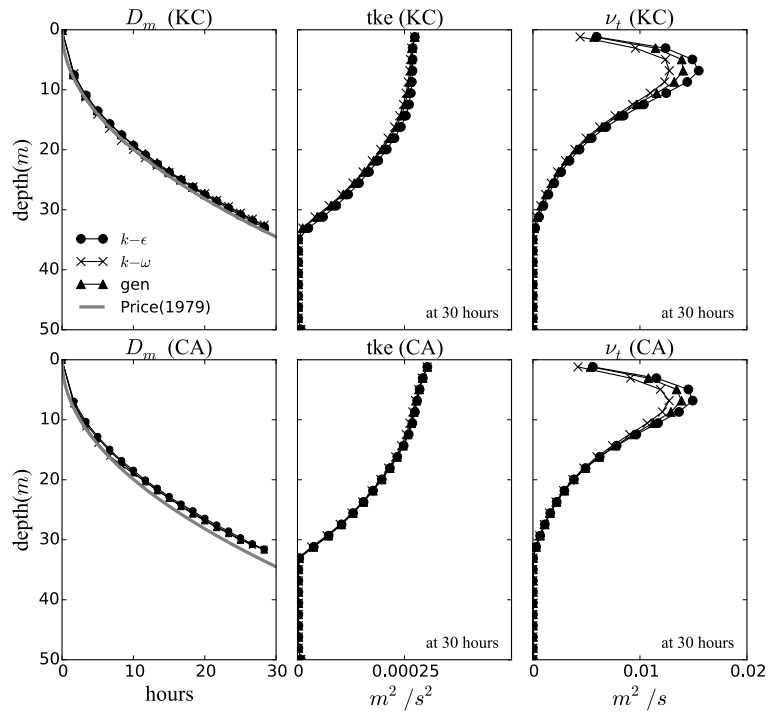

図-3 混合層低下の比較結果 (上 : KC,下 : CA) 左 : 混合層厚 , 中 : 乱流エネルギー，右：渦動粘性係数

ネルギーと渦動粘性係数の鉛直分布は, 乱流モデル及 び Stability function の選択の影響を受け, 差が生じる 結果となった . 結果のばらつきの傾向は異なるものの， Warner et al. ${ }^{10)}$ にも同程度の差異がみられる. 本解析か らは, 壁法則との一致という観点では, 乱流エネルギー に対してはgen と KC の組み合わせ , そして渦動粘性 係数に対しては $k-\epsilon$ KC の組み合わせが良好である という結果になった．しかしながら，全ケースの違い はさほど大きくなく, 定常開水路流れに関してはどの ようなモデル選択を行っても問題ないと思われる .

\section{(2) 混合層低下現象}

多くの研究 ${ }^{10,12,17)}$ で検証に用いられている風応力 に伴う混合層低下現象を数値計算で再現した.計算条件 は, 水深 $50 \mathrm{~m}$ で無限に長い一次元水路を前節で説明し た周期境界条件によって再現した .この計算は Kato and Phillips $^{24)}$ の室内実験を現地スケールで模するものであ る. Cell オブジェクトの形状は, 水平方向が一辺 $100 \mathrm{~m}$ の正三角形, 光して鉛直方向は $0.25 \mathrm{~m}$ 厚とし, 図-1(c) のようにオブジェクトを並べた . また, 計算時間ステッ プは 30 秒とした . 初期温度分布は水面が $13^{\circ} \mathrm{C}$, 底面で $10^{\circ} \mathrm{C}$ なるような線形成層とし, 水面に作用する風応力 が $0.01 \mathrm{~N} / \mathrm{m}^{2}$ となるように風速を調整した . また, 混合 層の深さの判定には, 乱流エネルギーが $k<10^{-5} \mathrm{~m}^{2} / \mathrm{s}^{2}$ となる深さを採用した . 計算結果の検証には, Price ${ }^{25)}$ の混合層深さ $D_{m}$ に関する経験式を利用した .

$$
D_{m}=1.05 u_{s}^{*} N_{0}^{-1 / 2} t^{1 / 2}
$$

ここで $u_{s}^{*}$ は水面での摩擦速度, $N_{0}$ は初期の浮力振動 数で, 本研究では $N_{0}=0.01 s^{-1}$ とした. 図-3 は混合層 厚の時間的変化に関して Price の経験式との比較, 光し て，風応力作用後 30 時間での乱流エネルギーと渦動粘 
性係数の鉛直分布を示している . 左側の混合層厚に関 しては, どの乱流モデルも同樣な変化傾向を示してお り，選択か結果にほとんど影響しないことがわかる.し かし, Stability function の選択に関しては, KC の方が 若干ではあるがPrice の式に近い結果を示している.乱 流エネルギーの鉛直分布はどのケースでも大きく違う ことはないが, 水面付近では CA のケースの方が大き くなる傾向は見られる.一方, 渦動粘性係数に関して は，極值を持つ付近で乱流モデルの差か現れた . 本シ ミュレーターで得られた乱流エネルギーと渦動粘性係 数の絶対值と分布形状を他の研究と比べると, Warner et al ${ }^{10)}$ よりも，当然のことながら Stability functionに同 じ係数群を利用している Hill et al. ${ }^{12)}$ や Burchard ${ }^{13)} の$ 結果に近いものとなった .

\section{5. まとめ}

本研究では, 非構造格子流体シミュレーターFantom Unstructuredへの GLS モデルの組み込みと精度検証を 行った . 得られた結論は以下の通りである.

- Fantom Unstructured $の$ Vertical membrane に乱流量 を配置して陰的な鉛直拡散計算を行うことによっ て, 数值的に安定した計算を行うことが出来た .

・定常開水路流れの再現計算では, どのモデルの組 み合わせも水平流速の鉛直分布か対数分布に近い 結果を得た。

- 風応力に伴う混合層低下の計算では, Kato and Phillips の結果を適切に再現することが出来た .

- 乱流エネルギーや渦動粘性係数の鉛直分布は, 乱 流モデルや Stability function によって差異があるこ とがわかった．しかしながら，光の差異が物質の 輸送や混合に大きな影響を与えるほどではないと 判断出来た。

\section{参考文献}

1) Munk, W. H. and Anderson, E. R.: Notes on a theory of the thermocline. J. Mar. Res., Vol.7(3), pp.276-295, 1948.

2) Hodges, B. R., Imberger, J., Saggio, A. and Winters, K. B.: Modeling basin-scale internal wave in a stratified lake. Limnol. Oceanogr., Vol.45(7), pp.1603-1620, 2000.

3) Large, W. G., McWilliams, J. C. and Doney, S. C.: Oceanic vertical mixing: a review and a model with nonlocal boundary layer parameterization. Review of Geophysics, Vol.32, pp.363-403, 1994.

4) Saffman, P. G.: A model for inhomogeneous turbulent flow. Proc. R. Soc., Lond. A, Vol.317, pp.417-433, 1970.

5) Jones, W. P. and Launder, B. E.: The prediction of laminarization with a two-equation model of turbulence. Int. J. Heat Mass Transfer, Vol.15, pp.301-314, 1972.

6) Mellor, G. L. and Yamada, T.: A hierarchy of turbulence closure models for planetary boundary layers. J. Atmos. sci., Vol.31, pp.1791-1806, 1974.
7) Umlauf, L. and Burchard, H.: A generic length-scale equation for geophysical turbulence models. J. Mar. Res., Vol.61, pp.235-265, 2003.

8) Burchard, H., Bolding, K. and Umlauf, L.: General Ocean Turbulence Model, http://www.gotm.net

9) Zhang, Y., Baptista, A. M. and Myers, E. P.: A cross-scale model for 3D baroclinic circulation in estuary-plume-shelf systems: I. Formulation and skill. Cont. Shelf. Res., Vol.24, pp.2187-2214, 2004.

10) Warner, J. C., Sherwood, C. R., Arango, H. G. and Signell, R. P.: Performance of four turbulence closure models implemented using a generic length scale method. Ocean Modelling, Vol.8, pp.81-113, 2005.

11) Wang, B., Griddings, S. N., Fringer, O. B., Fong, D. A. and Monismith, S. G.: Modeling and understanding turbulent mixing in a macrotidal salt wedge estuary. J. Geophys. Res., Vol.116, C02036, 2011.

12) Hill, J., Piggott, M. D., Ham, D. A., Popova, E. E. and Srokosz, M. A.: On the performance of a generic length scale turbulence model within an adaptive finite element ocean model. Ocean Modelling, Vol.56, pp.1-15, 2012.

13) Burchard, H.: Applied turbulence modelling in marine waters, Lecture notes in earth sciences, Vol.100, Springer, 2002.

14) 森 信人·佐地泰昭·重松孝昌 -中尾正喜·矢持 進 ·間瀬 肇: 海洋モデルによる気象変動を考慮した大阪湾への都市排 熱放出の影響評価. 土木学会論文集 B2(海岸工学), Vol.66, No.1, pp.1296-1300, 2010.

15) 木村延明: 小規模な浅い湖における日変化する物理過程 の研究. 環境水理部会研究集会概要集, on web, 2015.

16) 新谷哲也・中山惠介: 生物細胞の組織構造を模した流体 シミュレーターの設計と検証. 土木学会論文集 B1(水工学), Vol.59, pp.I_751-I_756, 2015.

17) Umlauf, L and Burchard, H: Second-order turbulence closure models for geophysical boundary layers. A review of recent work. Cont. Shelf. Res., Vol.25, pp.795-827, 2005.

18) Kantha, L. H. and Clayson, C. A.: An improved mixed layer model for geophysical applications. J. Geophys. Res., Vol.99(C12), pp.25235-25266, 1994.

19) Canuto, V. M., Howard, A., Cheng, Y., and Dubovikov: Ocean turbulence I: One-point closure model -Momentum and heat vertical diffusivities. J. Phys. Oceanogr., Vol.31, pp.1413-1426, 2001.

20) http://eigen.tuxfamily.org/

21) Platzek, F. W., Stelling, G. S., Jankowski, J. A. and Pietrzak, J.D.: Accurate vertical profiles of turbulent flow in z-layer models. Water Resour. Res., Vol.50, doi:10.1002/2013WR014411, 2014.

22) 近藤純正編著: 水環境の気象学, 朝倉書店,350p, 1994.

23) Galperin, B., Kantha, L. H., Hassid, S. and Rosati, A.: A quasi-equilibrium turbulent energy model for geophysical flows. J. Atomos. Sci., Vol.45, pp.55-62, 1988.

24) Kato, H. and Phillips, O. M.: On the penetration of a turbulent layer into a stratified fluid. J. Fluid Mech., Vol.37, pp.643-655, 1969.

25) Price, J. F.: On the scale of stress-driven entrainment experiments. J. Fluid Mech., Vol.90, pp.509-529, 1979.

(2015.9.30 受付) 